\title{
Early albumin infusion to infants at risk for respiratory distress
}

\author{
R. D. BLAND, T. L. CLARKE, L. B. HARDEN, JUDITH L. MEYER, J. P. RIES, \\ W. A. MADDEN, F. W. CRAST, W. F. COYER, and J. W. BASS \\ From the Department of Pediatrics, Tripler Army Medical Center, Honolulu, Hawaii
}

\begin{abstract}
Bland, R. D., Clarke, T. L., Harden, L. B., Meyer, J. L., Ries, J. P., Madden, W. A., Crast, F. W., Coyer, W. F., and Bass, J. W. (1973). Archives of Disease in Childhood, 48, 800. Early albumin infusion to infants at risk for respiratory distress. In a randomized prospective study, 100 high-risk infants (selected on the basis of a cord serum protein level of $4.6 \mathrm{~g} / 100 \mathrm{ml}$ or less, gestational age under 37 weeks, birthweight $2500 \mathrm{~g}$ or less, and/or arterial $p \mathrm{H}$ below $7 \cdot 25$ ) received $8 \mathrm{ml} / \mathrm{kg}$ of either $25 \%$ salt-poor albumin or $5 \%$ dextrose in water before the age of 2 hours. All infants were then managed supportively with warmth, appropriate oxygen supplementation, isotonic fluid infusion, and close monitoring, without further administration of colloid or hypertonic alkali solutions over the first 4 hours of life.

No statistically significant difference was shown between early colloid and early dextrose-water administration for either the incidence of idiopathic respiratory distress syndrome (RDS) or the mortality of high-risk infants, suggesting no apparent advantage of albumin over simple glucose-water infusion to hypoproteinaemic newborns shortly after birth. However, among the infants of 28 weeks' gestation or less admitted to the study, 3 of 4 albumin-treated patients survived, while 5 comparable infants in the dextrose-water group died within 12 hours of birth.

For the 100 infants taken together there was a significant improvement in morbidity and mortality from previous experience in the same nursery, indicating that prompt supportive care, including early fluid administration, may be instrumental in reducing the incidence and severity of RDS.
\end{abstract}

The association of systemic hypotension (Rudolph et al., 1961; Neligan and Smith, 1960) and pulmonary ischaemia (Chu et al., 1967) with the development of the idiopathic respiratory distress syndrome (RDS) suggests that immediate measures to combat shock shortly after birth may be a critical step in the management of the 'high-risk' infant. It has been proposed that the administration of a placental transfusion or delayed clamping of the cord results in a diminished incidence of hyaline membrane disease (Moss, Duffie, and Fagan, 1963; Oh et al., 1967; Bound, Harvey and Bagshaw, 1962; Emmanouilides and Moss, 1971) and that mortality from the disease is reduced by the early infusion of colloid to low birthweight, hypoproteinaemic infants (Cooke, 1960). A communication by Fraillon and Kitchen (1962) failed to substantiate the efficacy of albumin administration, though the

Received 8 March 1973. experimental design differed significantly from that of the previous study.

In a recent report it was shown that over $95 \%$ of newborn infants who develop RDS may be detected within minutes of birth by a simple refractometric measurement of the total serum protein content of umbilical cord venous blood (Bland, 1972). In the same study it was shown that RDS occurs in over one-third of newborn infants with a cord protein level of $4.6 \mathrm{~g} / 100 \mathrm{ml}$ or less and in one-half of all low birthweight $(<2500 \mathrm{~g})$ or preterm $(<37$ weeks' gestation) infants with low cord serum proteins, thereby establishing the 'high-risk' nature of this group of infants.

In an effort to resolve the conflicting results of previous clinical trials, a prospective evaluation of early fluid and colloid infusions to randomized, preterm, low birthweight hypoproteinaemic infants was undertaken. We report on the morbidity and mortality of 100 infants admitted to the study. 
Material and methods

A stoppered glass tube of umbilical cord venous blood, from each neonate admitted to the Tripler General Hospital newborn nursery during the course of this study, was used for investigation. A small amourit of serum was extracted from the cord blood sample after centrifugation for rapid determination of serum total protein level by a modified refractometric technique requiring only one drop of undiluted serum transferred by pipette onto a hand refractometer (Wolf et al., 1962). Previous experience with this method has shown that these simplified protein measurements are not only rapid, reproducible, and inexpensive to perform, but they correlate well with levels obtained by the biuret method $(r=0.958)$ (Bland, 1972).

Infants were weighed on admission and gestational age was assessed on the basis of maternal menstrual history and obstetric milestones, adjusted according to various physical (Usher, McLean, and Scott, 1966) and neurological (Koenigsberger, 1966) criteria for maturity.

Criteria for admission to the study were as follows. Cord serum protein level $\leqslant 4 \cdot 6 \mathrm{~g} / 100 \mathrm{ml}$ and at least one of the following. (a) Birthweight $\leqslant 2500$ g. (b) Gestational age $<37$ weeks. (c) Arterial (or 'arterialized capillary') $p \mathrm{H}<7 \cdot 25$. $\quad$ The investigation included only infants with spontaneous respirations at the time of their arrival in the nursery.

When the above standards were met, peripheral blood haematocrit and total serum protein determinations were carried out, and a clinical assessment of respiratory distress was recorded using the 0-10 scale of Silverman and Andersen (1956). Therapy cards were randomized in pairs matched for weight. A card was then selected instructing the nurse to draw up $8 \mathrm{ml} / \mathrm{kg}$ of either $5 \%$ dextrose in water or $25 \%$ salt-poor albumin + in a sterile $30 \mathrm{ml}$ syringe.

Informed consent of one or both parents was obtained for all infants admitted to the study. Within 2 hours of birth, most often in the first 20 minutes, a polyethylene

^TS meter, model number 10400: American Optical Corporation, Scientific Instrument Division, Buffalo, N.Y., U.S.A.

tDetermined on the Instrumentation Laboratory Inc. (Boston, Mass., U.S.A.) blood gas analyzer, model number 127.

¥Albumin, Normal Human Serum, U.S.P., Salt Poor. Metrix, Clinical and Diagnostics Division, Armour Pharmaceutical Company, Chicago, Illinois, U.S.A. catheter was inserted into the umbi ical vein through the ductus venosus to the inferior vena cava where venous pressure was taken, followed by the infusion of the albumin or glucose-water over a 5- to 10-minute period. The catheter was removed promptly and if there was any evidence of sustained distress, a peripheral venous line or an indwelling umbilical arterial catheter was inserted. A chest $x$-ray was obtained in all cases, and arterial blood gas determinations were made as indicated to assess the degree of acidosis and right-to-left shunting. After the initial infusion of fluid or colloid, all infants were managed supportively with warmth, appropriate oxygen supplementation, isotonic fluid administration, and close monitoring without further infusion of colloid or hypertonic alkali solutions over the first 4 hours of life.

A diagnosis of RDS was established on the basis of a sustained respiratory rate greater than 60 per minute, repeated observations of xiphoid retraction, an expiratory grunt, and cyanosis out of oxygen, with symptoms of at least 72 hours' duration or until death, thereby excluding all cases of transient neonatal tachypnoea. $X$-ray evidence of a granular pulmonary pattern with 'air bronchograms' was shown for all infants in whom a diagnosis of RDS was made.

Therapeutic failures were defined as all infants who died within the first 28 days after birth, in addition to those infants who required continuous assisted ventilation for more than 2 hours to maintain life. The criteria for initiation of assisted ventilation included (1) sustained apnoea, or (2) persistent arterial oxygen tension $<40$ $\mathrm{mmHg}$ in $100 \%$ oxygen, accompanied by a falling $\mathrm{pH}$ $<7 \cdot 20$.

Daily determinations of peripheral blood haematocrit, total serum protein level, and total and direct-reacting bilirubin were made over the first 5 days of life, as well as clinical assessment of distress, blood gas determinations, and chest $x$-ray, as indicated. Antibiotics were not administered routinely. At the conclusion of 50 paired clinical trials, results were assessed for significance by $\chi^{2}$ analysis.

\section{Results}

As noted in Table $I$, the group that received salt-poor albumin was strikingly similar to the group that received dextrose in water, except for the

TABLE I

Summary of comparative data for infants in the two therapy groups

\begin{tabular}{|c|c|c|}
\hline & $\begin{array}{l}\text { Infants given } 8 \mathrm{ml} / \mathrm{kg} \\
5 \% \text { dextrose in water }\end{array}$ & $\begin{array}{l}\text { Infants given } 8 \mathrm{ml} / \mathbf{k g} \\
\text { salt-poor albumin }\end{array}$ \\
\hline $\begin{array}{l}\text { (1) No. } \\
\text { (2) Males } \\
\text { (3) Females } \\
\text { (4) Gestational age (wk) } \\
\text { (5) Birthweight (g) } \\
\text { (6) Initial pH } \\
\text { (7) Cord total serum protein level }(\mathrm{g} / 100 \mathrm{ml})\end{array}$ & $\begin{array}{l}50 \\
25 \\
25 \\
33 \cdot 7(0 \cdot 4) \\
1925(79) \\
7 \cdot 28(0 \cdot 015) \\
4 \cdot 0(0 \cdot 07)\end{array}$ & $\begin{array}{l}50 \\
29 \\
21 \\
33 \cdot 6(0 \cdot 4) \\
2003(85) \\
7 \cdot 28(0 \cdot 015) \\
4 \cdot 1(0 \cdot 05)\end{array}$ \\
\hline
\end{tabular}

^Figures for categories 4-7 represent mean value and SEM. 
TABLE II

Comparison of morbidity and mortality results between dextrose-water and albumin-treated groups, and a group of similar high-risk infants previously managed without early infusions

\begin{tabular}{|c|c|c|c|}
\hline & $\begin{array}{c}\text { Dextrose-water } \\
\text { group }\end{array}$ & $\begin{array}{l}\text { Albumin } \\
\text { group }\end{array}$ & $\begin{array}{c}\text { Infants with } \\
\text { low cord proteins }(\leqslant 4 \cdot 6) \text {, } \\
\text { immaturity }(<37 \mathrm{wk})\end{array}$ \\
\hline $\begin{array}{l}\text { No. of infants } \\
\text { Incidence of RDS (\%) } \\
\text { Total mortality (\%) } \\
\text { (from RDS and non-RDS) } \\
\text { Therapeutic failures (\%) (includes infants } \\
\text { who died and those who survived by } \\
\text { assisted ventilation) }\end{array}$ & $\begin{array}{l}50 \\
16(32 \%) \\
12(24 \%) \\
15(30 \%)\end{array}$ & $\begin{array}{l}50 \\
14(28 \%) \\
9(18 \%) \\
11(22 \%)\end{array}$ & $\begin{array}{l}58 \\
30(51 \cdot 7 \%) \\
20(34 \cdot 5 \%) \\
21(36 \cdot 2 \%)\end{array}$ \\
\hline
\end{tabular}

slight difference in sex distribution, with more males among the albumin-treated infants. There was no significant difference between the two groups for gestational age, birthweight, initial $p \mathrm{H}$, or cord serum protein level.

From Table II it can be seen that the control (dextrose-water) group had an RDS incidence of $32 \%$ compared to the $28 \%$ in the albumin-treated group. The mortality rate was $24 \%$ in the control group and $18 \%$ in the colloid-infusion group. Neither of these differences is statistically significant $(P>0 \cdot 1)$.

Among the nonsurvivors treated with albumin, 8 of 9 had severe hyaline membrane disease at necropsy examination, while 1 infant died of sepsis and necrotizing enterocolitis 8 days after birth. The median duration of life for this group was 21 hours, with a range of 6 hours to 8 days (only 1 infant expired after 72 hours).

Likewise, hyaline membranes were shown in 8 of the 12 deaths in the dextrose-water group, including 1 infant who died at 28 days of age with pulmonary oxygen toxicity. 2 patients in this group succumbed to pneumonia and sepsis; 1 infant had immature lungs without hyaline membranes; and in another, sudden death at $2 \frac{1}{2}$ hours of age was preceded by unexplained shock. The median duration of life in this group was 17 hours, with a range of $2 \frac{1}{2}$ hours to 28 days.
In order to eliminate as a variable the progressive improvement in the management of assisted ventilation during the course of the study, those who survived only by respirator therapy were included among the 'therapeutic failures'. As in the comparisons between the two treatment groups for incidence of RDS and mortality, there was not a statistically significant difference for therapeutic failures, suggesting that there is no apparent advantage of early colloid vs glucose-water administration for high-risk infants. Yet when the incidence of RDS among all infants in the study was compared to the incidence in a similar group of infants previously managed with a less aggressive approach (Bland, 1972), there was a statistically significant difference $(\mathrm{P}<0 \cdot 01)$.

In Tables III and IV figures for incidence of RDS, mortality, and therapeutic failures are listed according to gestational age and birthweight groups respectively, revealing a comparable distribution of outcomes except in the very immature group where the numbers are insufficient for a meaningful comparison. Among the smallest, most premature infants, 3 of 4 albumin-treated patients survived, while all 5 comparable infants in the dextrose-water group died within 12 hours of birth, suggesting that further studies of very small, premature infants may be warranted.

Table $\mathrm{V}$ analyses the incidence of RDS and

TABLE III

Incidence of RDS, mortality, and therapeutic failures for the two therapy groups according to gestational age

\begin{tabular}{|c|c|c|c|c|c|c|c|c|}
\hline \multirow{2}{*}{$\begin{array}{c}\text { Gestational age } \\
(w k)\end{array}$} & \multicolumn{4}{|c|}{$\begin{array}{l}\text { Infants given } 8 \mathrm{ml} / \mathrm{kg} \\
5 \% \text { dextrose in water }\end{array}$} & \multicolumn{4}{|c|}{$\begin{array}{l}\text { Infants given } 8 \mathrm{ml} / \mathrm{kg} \\
\text { salt-poor albumin }\end{array}$} \\
\hline & $\begin{array}{l}\text { No. } \\
\text { of infants }\end{array}$ & RDS & Death & $\begin{array}{l}\text { Treatment } \\
\text { failure }\end{array}$ & $\begin{array}{l}\text { No. } \\
\text { of infants }\end{array}$ & RDS & Death & $\begin{array}{l}\text { Treatment } \\
\text { failure }\end{array}$ \\
\hline $\begin{array}{c}\leqslant 28 \\
29-32 \\
33-36 \\
\geqslant 37\end{array}$ & $\begin{array}{r}5 \\
10 \\
27 \\
8\end{array}$ & $\begin{array}{l}4 \\
3 \\
6 \\
3\end{array}$ & $\begin{array}{l}5 \\
3 \\
3 \\
1\end{array}$ & $\begin{array}{l}5 \\
3 \\
6 \\
1\end{array}$ & $\begin{array}{r}4 \\
9 \\
35 \\
2\end{array}$ & $\begin{array}{l}1 \\
5 \\
8 \\
0\end{array}$ & $\begin{array}{l}1 \\
4 \\
4 \\
0\end{array}$ & $\begin{array}{l}1 \\
5 \\
5 \\
0\end{array}$ \\
\hline
\end{tabular}


TABLE IV

Incidence of RDS, mortality, and therapeutic failures for the two therapy groups according to birthweight

\begin{tabular}{|c|c|c|c|c|c|c|c|c|}
\hline \multirow{2}{*}{ Birthweight (g) } & \multicolumn{4}{|c|}{$\begin{array}{l}\text { Infants given } 8 \mathrm{ml} / \mathrm{kg} \\
5 \% \text { dextrose in water }\end{array}$} & \multicolumn{4}{|c|}{$\begin{array}{l}\text { Infants given } 8 \mathrm{ml} / \mathrm{kg} \\
\text { salt-poor albumin }\end{array}$} \\
\hline & $\begin{array}{l}\text { No. } \\
\text { of infants }\end{array}$ & RDS & Death & $\begin{array}{c}\text { Treatment } \\
\text { failure }\end{array}$ & $\begin{array}{l}\text { No. } \\
\text { of infants }\end{array}$ & RDS & Death & $\begin{array}{c}\text { Treatment } \\
\text { failure }\end{array}$ \\
\hline $\begin{array}{c}\leqslant 1000 \\
1001-1500 \\
1501-2000 \\
2001-2500 \\
>2500\end{array}$ & $\begin{array}{r}3 \\
8 \\
14 \\
20 \\
5\end{array}$ & $\begin{array}{l}3 \\
2 \\
4 \\
4 \\
3\end{array}$ & $\begin{array}{l}3 \\
4 \\
3 \\
1 \\
1\end{array}$ & $\begin{array}{l}3 \\
4 \\
3 \\
4 \\
1\end{array}$ & $\begin{array}{r}3 \\
8 \\
12 \\
18 \\
9\end{array}$ & $\begin{array}{l}0 \\
4 \\
5 \\
4 \\
1\end{array}$ & $\begin{array}{l}0 \\
3 \\
4 \\
1 \\
1\end{array}$ & $\begin{array}{l}0 \\
4 \\
4 \\
1 \\
2\end{array}$ \\
\hline
\end{tabular}

TABLE V

Outcome of albumin infusion study according to sex distribution

\begin{tabular}{|c|c|c|c|c|c|c|}
\hline & \multicolumn{3}{|c|}{$\begin{array}{l}\text { Dextrose-water group } \\
(25 \text { males, } 25 \text { females })\end{array}$} & \multicolumn{3}{|c|}{$\begin{array}{l}\text { Albumin group } \\
\text { (29 males, } 21 \text { females) }\end{array}$} \\
\hline & Male & Female & Total & Male & Female & Total \\
\hline $\begin{array}{l}\text { RDS } \\
\text { Death } \\
\quad \text { (RDS/non-RDS) } \\
\text { Failures }\end{array}$ & $\begin{array}{l}6 \\
3 \\
3\end{array}$ & $\begin{array}{r}10 \\
9 \\
12\end{array}$ & $\begin{array}{l}16 \\
12 \\
15\end{array}$ & $\begin{array}{l}6 \\
4 \\
4\end{array}$ & $\begin{array}{l}5 \\
7\end{array}$ & $\begin{array}{r}14 \\
9 \\
11\end{array}$ \\
\hline
\end{tabular}

mortality according to sex distribution for the two groups. It is apparent that females were more commonly and more severely affected with both treatment regimens, making it unlikely that the difference in sex distribution had a significant effect on the outcome of the study.

As shown in the Fig., peak total bilirubin levels were almost identical for both groups $(11 \cdot 4 \pm 0 \cdot 65$ in the infants treated with dextrose-water vs $11 \cdot 7 \pm 0 \cdot 60$ in the albumin-treated infants), as were peripheral haematocrit and total serum protein levels from 24 hours to 5 days after infusion. During the first day of life, haematocrit levels were lower $(P<0.05$, by Student's ' $t$ ' test analysis) and serum protein measurements were higher $(P<0.05)$ in the albumin-treated infants, consistent with a transitory colloid osmotic effect.

\section{Discussion}

The histological finding that pulmonary hyaline membranes are made up of fibrin derived from an antecedent state of effusion (Gitlin and Craig, 1956) led Cooke (1960) to propose that the serum albumin level may be an important variable in the development of 'the pulmonary hyaline membrane syndrome'. He reported that the administration of salt-poor albumin in a dose of $4 \mathrm{ml} / 454 \mathrm{~g}$ body weight to premature newborns with serum protein levels of less than $5 \mathrm{~g} / 100 \mathrm{ml}$ resulted in a significant diminution in the incidence of, and mortality from,
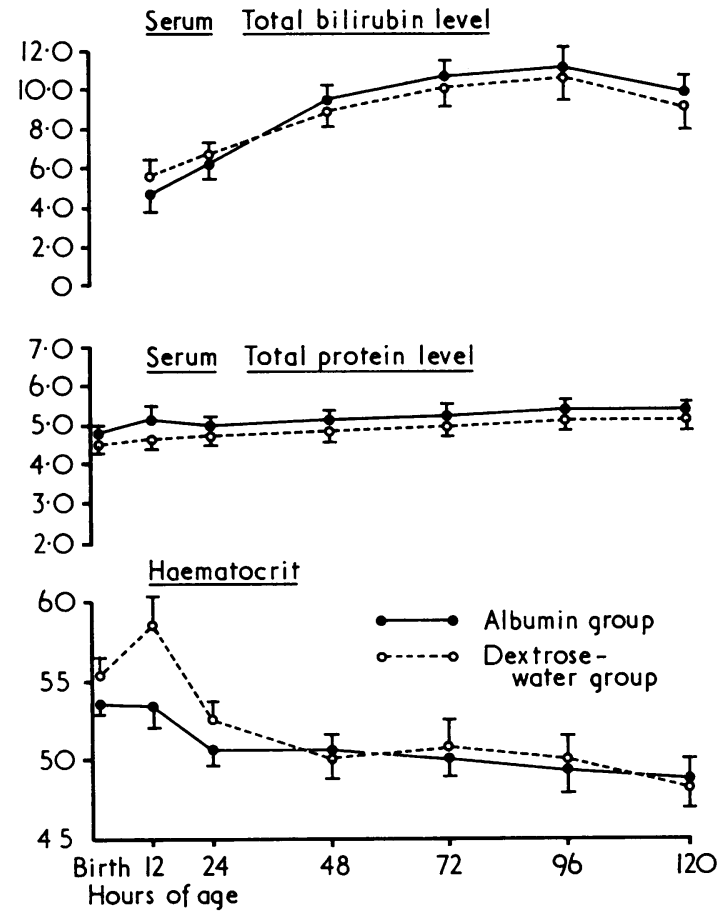

FIG.-Serial determinations (mean and SEM) of serum total bilirubin levels in $\mathrm{mg} / 100 \mathrm{ml}$, total serum protein levels in $\mathrm{g} / 100 \mathrm{ml}$, and peripheral blood haematocrits, taken from capillary samples of infants admitted to the study. 
hyaline membrane disease. In that work, however, the control group did not undergo umbilical catheterization nor was a placebo solution administered.

A subsequent study, reported by Fraillon and Kitchen (1962), refuted the beneficial effect of early albumin infusions, though that investigation was performed on consecutive rather than randomlyselected simultaneous populations, $10 \mathrm{ml}$ samples of blood were withdrawn before administration of colloid, and the treated group was selected strictly on the basis of weight $(<2500 \mathrm{~g})$, not protein levels; consequently, only 26 of the 54 patients receiving albumin had protein levels of $<5 \mathrm{~g} / 100 \mathrm{ml}$. Of those 26 , only 1 died with hyaline membrane disease, compared with 9 of 119 in the control group. Several others died of 'other pulmonary disease', perhaps related to the design of the study-without any measurement of cardiovascular status or knowledge of serum protein levels, administration of salt-poor albumin to some of these babies may have resulted in the development of hypervolaemia and pulmonary oedema. Their conclusions that 'the use of concentrated salt-poor human albumin in the first hour of life does not affect neonatal mortality or the incidence of hyaline membrane disease', though founded on a tenuous experimental design and statistical analysis, brought a halt to further investigation of this therapeutic regimen.

Based on the apparent inconsistencies of these previous reports and the fact that such a high percentage of infants with RDS are hypoproteinaemic and hypotensive with inadequate peripheral perfusion, this study was undertaken in an attempt to resolve the efficacy of early colloid administration to 'high-risk' infants. The discovery of, at best, a marginal advantage of such infusions over glucose-water alone in the management of RDS is not surprising in light of the transitory effect of albumin infusions on neonatal blood volume (Smith, Phillips, and Roth, 1950) and the limited data which are available on the osmotic effect of stored albumin. The studies of Hinkley and Blechner (1969) and Delivoria-Papadopoulos, Battaglia, and Meschia (1969) showed that the colloid osmotic pressure (COP) of fetal and newborn plasma proteins is low by adult standards. In addition, the more recent report of Baum et al. (1971) showed that not only is COP directly related to gestational age, but it was also noted that the commercially available albumin preparations may be even less osmotically active than the native newborn plasma colloids, presumably because of molecular aggregation during storage or administration.

The possible implications of the quantitative and qualitative deficits in plasma proteins of preterm infants towards the pathogenesis of hyaline membrane disease are notable. In accord with the Starling hypothesis (1896), the presence of hypoproteinaemia with reduced colloid osmotic pressure, in conjunction with raised pressures in the pulmonary circulation of preterm newborns (many of whom are stressed by hypoxaemia and acidaemia), may be expected to yield extravasation of fluid and protein into the lungs. The resultant pulmonary oedema may have an adverse influence on surfactant activity with associated atelectasis, as has been shown by previous investigators (Said et al., 1965; Tierney and Johnson, 1965; Taylor and Abrams, 1966).

The speculation that pulmonary oedema may be a critical component of RDS is supported by histological findings at necropsy (Gandy, Jacobson, and Gairdner, 1970), by the demonstration of dilated, engorged pulmonary lymphatic channels in newborn infants with the disease (Lauweryns, Claessens, and Boussauw, 1968), and by biochemical data from experimentally induced disease in fetal lambs (Adams, Fujiwara, and Latta, 1971). Moreover, it is consistent with the discovery that lungs from infants who die with hyaline membranes are heavier than those of newborns who succumb from other causes (Naeye, Harcke, and Blanc, 1971). It may afford some insight into the clinical observation that recovery from the disease is associated with diuresis.

Speculation aside, the overall improvement in morbidity and mortality for the 100 patients included in this study in comparison with those of a comparable group, managed with less vigor at an earlier date, suggests that intensive supportive care of high-risk newborn infants by careful thermoregulation, oxygenation, fluid administration, and constant monitoring in conjunction with prudent utilization of continuous positive airway pressure is of significant benefit.

We thank the nursing staff of the Tripler General Hospital newborn nurseries for their assistance; Dr. Richard Jones for his help with statistical analysis; $\mathrm{Mr}$. Charles Matsuda for the illustration; and Mrs. Millie Cheong, Mrs. Lois Masunaga, and Ms. Kathleen Bryan for secretarial assistance.

This work was supported in part by the U.S. Army Research and Development Command. A portion of this paper was presented in conjunction with a previous report on Cord Proteins and RDS at the Uniformed Services Pediatric Seminar, San Francisco, California, March, 1972, where it was granted the fourth annual Ogden C. Bruton Award.

\section{REFERENCES}

Adams, F. H., Fujiwara, T., and Latta, H. (1971). 'Alveolar' and whole lung phospholipids of premature newborn lambs. Biology of the Neonate, 17, 198. 
Baum, J. D., Eisenberg, C., Franklin, F. A., Jr., Meschia, G., and Battaglia, F. C. (1971). Studies on colloid osmotic pressure in the fetus and newborn infant. Biology of the Neonate, 18, 311

Bland, R. D. (1972). Cord-blood total protein level as a screening aid for the idiopathic respiratory-distress syndrome. New England fournal of Medicine, 287, 9.

Bound, J. P., Harvey, P. W., and Bagshaw, H. B. (1962). Prevention of pulmonary syndrome of the newborn. Lancet, 1 , 1200.

Chu, J., Clements, J. A., Cotton, E. K., Klaus, M. H., Sweet, A. Y., and Tooley, W. H. (1967). Neonatal pulmonary ischemia. I. Clinical and physiological studies. Pediatrics, 40, 709.

Cooke, W. D. D. (1960). The prognostic significance of the serum protein content in premature babies and its relation to pulmonary hyaline membrane: preliminary communication. Medical fournal of Australia, 1, 887.

Delivoria-Papadopoulos, M., Battaglia, F. C., and Meschia, G. (1969). A comparison of fetal versus maternal plasma colloidal osmotic pressure in man. Proceedings of the Society for Experimental Biology and Medicine, 131, 84.

Emmanouilides, G. C., and Moss, A. J. (1971). Respiratory distress in the newborn. Effect of cord clamping before and after onset of respiration. Biology of the Neonate, 18, 363 .

Fraillon, J. M. G., and Kitchen, W. H. (1962). The relationship between serum protein levels and hyaline membrane disease in premature babies. Medical fournal of Australia, 2, 941.

Gandy, G., Jacobson, W., and Gairdner, D. (1970). Hyaline membrane disease. I. Cellular changes. Archives of Disease in Childhood, 45, 289.

Gitlin, D., and Craig, J. M. (1956). The nature of the hyaline membrane in asphyxia of the newborn. Pediatrics, 17, 64.

Hinkley, C. M., and Blechner, J. N. (1969). Colloidal osmotic pressures of human maternal and fetal blood plasma. American fournal of Obstetrics and Gynecology, 103, 71 .

Koenigsberger, M. R. (1966). Judgment of fetal age. I. Neurologic evaluation. Pediatric Clinics of North America, 13, 823.

Lauweryns, J. M., Claessens, St., and Boussauw, L. (1968). The pulmonary lymphatics in neonatal hyaline membrane disease. Pediatrics, 41, 917.

Moss, A. J., Duffie, E. R., and Fagan, L. M. (1963). Respiratory distress syndrome in the newborn. Study on the association of cord clamping and the pathogenesis of distress. Fournal of the American Medical Association, 184, 48.
Naeye, R. L., Harcke, H. T., and Blanc, W. A. (1971). Adrenal gland structure and the development of hyaline membrane disease. Pediatrics, 47, 650.

Neligan, G. A., and Smith, C. A. (1960). The blood pressure of newborn infants in asphyxial states and in hyaline membrane disease. Pediatrics, 26, 735.

Oh, W., Wallgren, G., Hanson, J. S., and Lind, J. (1967). The effects of placental transfusion on respiratory mechanics of normal term newborn infants. Pediatrics, 40, 6.

Rudolph, A. M., Drorbaugh, J. E., Auld, P. A. M., Rudolph, A. J., Nadas, A. S., Smith, C. A., and Hubbell, J. P. (1961). Studies on the circulation in the neonatal period. The circulation in the respiratory distress syndrome. Pediatrics, 27, 551.

Said, S. I., Avery, M. E., Davis, R. K., Banerjee, C. M., and ElGohary, M. (1965). Pulmonary surface activity in induced pulmonary edema. Fournal of Clinical Investigation, 44, 458.

Silverman, W. A., and Andersen, D. H. (1956). A controlled clinical trial of effects of water mist on obstructive respiratory signs, death rate, and necropsy findings among premature infants. Pediatrics, 17, 1.

Smith, C. A., Phillips, K. G., and Roth, R. O. (1950). Effects and fate of human serum albumin administered intravenously and orally to premature infants. Fournal of Clinical Investigation, 29, 218.

Starling, E. H. (1896). On the absorption of fluids from the connective tissue spaces. Fournal of Physiology, 19, 312.

Taylor, F. B., Jr., and Abrams, M. E. (1966). Effect of surface active lipoprotein on clotting and fibrinolysis, and of fibrinogen on surface tension of surface active lipoprotein. American Fournal of Medicine, 40, 346.

Tierney, D. F., and Johnson, R. P. (1965). Altered surface tension of lung extracts and lung mechanics. Fournal of Applied Physiology, 20, 1253.

Usher, R., McLean, F., and Scott, K. E. (1966). Judgment of fetal age. II. Clinical significance of gestational age and an objective method for its assessment. Pediatric Clinics of North America, 13, 835.

Wolf, A. V., Fuller, J. B., Goldman, E. J., and Mahony, T. D. (1962). New refractometric methods of the determination of total proteins in serum and in urine. Clinical Chemistry, 8, 158.

Correspondence to Dr. R. D. Bland, Cardiovascular Research Institute, University of California, San Francisco, California 94143, U.S.A. 